\title{
FUNGSI ARSITEKTUR RUMAH TRADISIONAL MASYARAKAT MELAYU JAMBI DI SEBERANG KOTA JAMBI
}

\author{
Maulana Kurniawan Putra ${ }^{1}$, Junita br Surbakti ${ }^{2}$, Mailinar ${ }^{3}$ \\ ${ }^{1,2,3}$ UIN Sulthan Thaha Saifuddin Jambi \\ surbaktijunita13@uinjambi.ac.id
}

\begin{abstract}
Abstrak
Tujuan penelitian ini adalah mendeskripsikan fungsi arsitektur rumah tradisional masyarakat melayu di seberang kota Jambi. Dari 3204 rumah yang ada, 3.315 rumah masih menggunakan atau bergaya rumah tradisional. Rumah kayu yang lebih populer dengan istilah Rumah Bengen merupakan warisan turun temurun yang fungsi arsitektur yang harus dipertahankan. Penelitian ini merupakan penelitian etnografi dengan menggunakan pendekatan fungsional. Data penelitian dikumpulkan menggunakan wawancara, observasi dan dokumentasi. Hasil penelitian menemukan bahwa arsitektur rumah tradisional melayu masyarakat seberang kota dalam pembuatan rumah tradisional menggunakan kayu keras pilihan seperti bilian Tembesu dan Meranti sebagai bahan utama. Rumah dengan arsitektur berpanggung, beranak tangga dibagian depan dan belakang, berkolam kecil didepan rumah, Daun pintu lawang dan bendul serta adanya pintu kecil khusus untuk hewan merupakan ciri khas arsitektur rumah tradisional masyarakat Melayu seberang kota Jambi. Arsitektur rumah tradisional masyarakat melayu seberang kota Jambi tidak jauh berbeda dengan rumah tradisional suku Melayu Sumatera Selatan, Riau dan Sumatera Barat, hal ini karena masyarakat melayu seberang kota Jambi masuk dalam rumpun Austranesia.
\end{abstract}

Keyword; Fungsi, Arsitektur, rumah tradisional melayu Jambi

\section{Pendahuluan}

Kekayaan budaya yang dimiliki setiap suku bangsa tidak hanya berbentuk sistem adat istiadat, tetapi kekayaan budaya bisa berbentuk material atau fisik. Tiap-tiap unsur kebudayaan universal itu termasuk dalam ketiga wujud kebudayaan yaitu wujud ideal, system sosial, dan kebudayaan fisik, yang di jelaskan oleh Cateora dikutip oleh Sulasman dalam buku Teori-teori Kebudayaan 
Maulana Kurniawan Putra, Junita Br Surbakti, Mailinar: Fungsi Arsitektur Rumah Tradisional Masyarakat Melayu Jambi di Seberang Kota Jambi

Dari Teori Hingga Aplikasi berdasarkan wujudnya, kebudayaan digolongkan menjadi dua komponen, yakni kebudayaan material dan kebudayaan nonmaterial.

Identitas budaya suku bangsa salah satu terlihat dari budaya material yang berbentuk benda, seperti rumah, rumah memiliki arti lebih dari sekedar pelindung yang pada akhirnya menentukan tempat tinggal dan membentuk ruang. Bangunan dan pemukiman merupakan gambaran hubungan penting dalam mengaitkan perbedaan aspek kehidupan dengan berbagai kenyataan yang ada. Rumah dengan tata ruang yang yang berbeda-beda bisa berfungsi sebagai tempat permusyawaratan, bahkan juga berfungsi sebagi tempat suatu upacara adat. Rapoport $(1979,2)$ mengatakan bahwa rumah merupakan bentuk kebudayaan yang paling dasar yang dimiliki oleh manusia. Dari hunian tersebut, budaya muncul. Dalam rumah tinggal, manusia pertama kali tumbuh untuk memahami nilai hubungan antar manusia dan spasialitas terhadap huniannya sebelum memahami spasialitas dan hubungan antar manusia di luar rumah. Ketika penghuni mengalami posisi transisi antara kebudayaan aslinya dengan kebudayaan baru yang masuk maka secara signifikan akan berpengaruh pula terhadap sistem yang terbentuk ke dalam rumah dan pekarangannya (Tarigan, $2015)^{1}$.

Arsitektur rumah tradisional merupakan representasi dari nilai budaya, dimana hunian atau rumah merupakan pengejawantahan paling dekat dengan kebudayaan manusia. Rumah tradisional yang menjadi simbol suku bangsa di dunia dengan berbagai fungsinya. Rumah tradisional dapat diartikan sebagai sebuah rumah yang dibangun dan digunakan dengan cara yang sama sejak beberapa generasi(Sumintardja, 1981) ${ }^{2}$, rumah tradisional juga merupakan suatu bangunan rumah yang mencirikan atau khas bangunan suatu daerah yang 
Maulana Kurniawan Putra, Junita Br Surbakti, Mailinar: Fungsi Arsitektur Rumah Tradisional Masyarakat Melayu Jambi di Seberang Kota Jambi

melambangkan kebudayaan dan ciri khas masyarakat setempat. Arsitektur rumah tradisional yang berbeda-benda tentunya mempuyai fungsi dan makna yang berbeda pula. Misalnya arsitektur tata ruang publik dan privat dengan model yang berbeda-beda pada rumah tradisional mayarakat Jawa mempunyai fungsi dan makna yang berbeda pula, dimana pembagian ruang menjadi area publik dan privat merupakan salah satu kunci dalam prinsip pengorganisasian dan pembentukan ruang fisik kota (Sudikno, Antariksa, 2016) ${ }^{3}$. Namun hal ini tidak terjadi pada semua suku bangsa yang masih mempertahankan rumah tradisional sebagai usaha untuk memelihara nilai-nilai budaya yang kian tergeser oleh budaya modernisasi.

Arsitektur Tata Ruang adalah tempat kehidupan yang mempunyai nilai fisik dan filosofis bagi penikmatnya, sedangkan perjalanan arsitektur merupakan perjalanan kebudayaan suatu bangsa. Manusia tidak akan lepas dengan apa yang dinamakan arsitektur, baik karakter lingkungan maupun identitas manusianya yang akan memberikan ungkapan fisik terhadap arsitektur tersebut. ${ }^{4}$ Arsitektur merupakan bagian dari kebudayaan dan manifestasi dari nilai-nilai budaya, baik nilai-nilai budaya perseorangan ataupun nilai-nilai budaya kelompok masyarakat. Oleh karena itu setiap pergeseran ataupun perubahan yang terjadi dalam kebudayaan akan mempengaruhi dinamika arsitektur. ${ }^{5}$

Tata Ruang merupakan hal yang khas pada setiap kelompok masyarakat. Konsep tata ruang suatu masyarakat banyak ditentukan oleh system budayanya, meliputi pengetahuan, kepercayaan, norma-norma dan aturan-aturan yang berlaku dalam masyarakat yang bersangkutan. Tata ruang suatu masyarakat sering pula

\footnotetext{
${ }^{4}$ Antariksa, pelestarian Arsitektur \& Kota yang Terpadu, (Universitas Cahaya Atma Jogjakarta, 2015), Hlm 39.

${ }^{5}$ Taufan Madiasworo, Tesis: Pengaruh Kebudayaan Banjar Terhadap Bentuk Rumah Panggung Masyarakat Banjar di Kampung Melayu Semarang, Universitas Diponegoro, Semarang 2001. Hlm. 13.
} 
Maulana Kurniawan Putra, Junita Br Surbakti, Mailinar: Fungsi Arsitektur Rumah Tradisional Masyarakat Melayu Jambi di Seberang Kota Jambi

merupakan simbolisasi dari kenyataan alam dan sosial budaya masyarakat tersebut. Tata ruang sangat penting dalam pembangunan, terutama terkait dengan pembangunan permukiman dan perwilayahan, karena setiap masyarakat memiliki konsep tertentu tentang tata ruang. Dengan mengerti dan memahami secara mendalam adat istiadat tentang keruangan suatu masyarakat, niscaya program pembangunan dengan permukiman dan perwilayahan tidak bertentangan dengan pandangan dan kebutuhan masyarakat bersangkutan.

Dilihat dari segi aspek arsitektural terutama tata ruangnya, semua bangunan rumah tradisional atau rumah adat di Indonesia mempunyai keunikan dan daya tarik tersendiri untuk ditelaah dan dipelajari lebih lanjut serta dikembangkan. Arsitektur tata tunag rumah tradisional memiliki banyak arti, makna serta fungsi yang dilengkapi dengan ornamen, serta elemen-elemennya. Rumah tradisional sebagai salah satu simbol atau ciri dari setiap daerah mempunyai konsep dan makna tersendiri bagi pemiliknya, misalnya masyarakat Baduy Dalam telah berpengalaman sejak lama dalam hal konservasi lingkungan yang dilaksanakan sebagai kearifan lokal terutama tercermin dalam pembangunan konstruksi rumah dengan menggunakan konsep ecohouse (Meiske Widyarti, Budi Indra Setiawan, Hadi Susilo Arifin, 2011) ${ }^{6}$. Jambi, khususnya masyarakat Suku Batin sampai saat ini masih mempertahankan adat-istiadat, terutama peninggalan-peninggalan adat berupa bangunan-bangunan tua.

Banyak rumah-rumah tradisional Suku Batin yang telah berusia sekitar 300 tahun dan menjadi obyek wisata yang menarik (Wiyana, 2016) ${ }^{7}$. Begitu juga dengan masyarakat Melayu Seberang Kota Jambi di kecamatan Palayangan, berdasarkan data terdapat 3.315 rumah dan 3204 masih menggunakan rumah tradisional atau rumah kayu, sisanya sebanyak 111 rumah menggunakan material 
Maulana Kurniawan Putra, Junita Br Surbakti, Mailinar: Fungsi Arsitektur Rumah Tradisional Masyarakat Melayu Jambi di Seberang Kota Jambi

semen. Informasi atau data lain juga menjelaskan bahwa 3204 rumah tradisional masyarakat Melayu seberang kota Jambi tradisional masih mempertahankan eksistensi arsitekrur rumah tradisional dan sekitar 30 rumah mengalami pembugaran oleh pemerintah. Penelitian ini dilakukan untuk mendeskripsikan mengapa sebagian masyarakat seberang masih mempertahankan model arsitektur rumah adat melayu Jambi; apa fungsi sosial yang terkandung dari model arsitektur tata ruang rumah adat melayu Jambi; dan meskripsikan bagaimana persepsi masyarakat tentang keberadaan rumah adat melayu Jambi.

Penelitian ini juga menggunakan penelitian etnografi yang memusatkan usahanya untuk menemukan bagaimana berbagai masyarakat mengorganisasikan budaya mereka dalam pikiran mereka dan kemudian menggunakan budaya tersebut dalam kehidupan, yang dimaksudkan ialah bentuk sosial dan budaya masyarakat tersebut dianggap merupakan susunan yang ada di dalam pikiran (mind) anggota masyarakat tersebut, dan tugas peneliti ialah mengoreknya keluar dari pikiran mereka. Data penelitian dikumpulkan melalui wawancara, observasi, dokumentasi. Adapun penentuan informan dilakukan dengan menggunakan teknik purposive sampling.

\section{Hasil dan Pembahasan}

Seberang Kota Jambi merupakan representasi kebudayaan lokal masyarakat kota Jambi yang mayoritas penduduknya beragam Islam. Penduduk yang berjumlah 13.445 menempati wilayah kecamatan Pelayangan bermata pencaharian tidak hanya sebagai petani, posisi yang berdekatan dengan sungai Batanghari membuat masyarakatnya juga ada yang bernata pencaharian sebagai nelayan, sebgain masyarakat ada juga yang berprofesi sebagai buruh tani, pedagang, buruh bangunan, sopir, pengrajin, dan Pegawai Negeri Sipil/PNS.

Seberang kota Jambi merupakan masyarakat yang masih memegang erat tradisi lokal salah satunya tradisi untuk mempertahankan aritektur rumah tradisional secara turun temuturun. Rumah tradisional sebagai produk kebudayaan, dimana kebudayaan merupakan milik bersama sebagai cara hidup 
Maulana Kurniawan Putra, Junita Br Surbakti, Mailinar: Fungsi Arsitektur Rumah Tradisional Masyarakat Melayu Jambi di Seberang Kota Jambi

yang berkembang dan diwariskan dari generasi kegenerasi. Rumah tradisional sebagi produk kebudayaan perwujudannya berupa benda-benda, merupakan hasil cipta manusia sebagai makhluk yang berbudaya seperti peralatan hidup yang bertujuan untuk membantu manusia untuk mempertahankan dan melangsungkan kehidupan bermasyarakat(Sulasman dkk, n.d.). ${ }^{8}$

Seberang Kota Jambi adalah wajah kota Jambi yang sebenarnya, dimana Seberang Kota Jambi ialah sebagai tempat warga asli melayu Jambi tinggal beserta adat istiadatnya, serta tradisi-tradisi yang masih mereka jaga secara turun temurun. Dalam konteks sistem teknologi dan peralatan hidup, manusia menciptakan rumah sebagai tempat untuk berlindung dan representasi dari identitas budaya dan sebagai produk kebudayaan yang di ciptakan manusia ianya berfungsi untuk memuaskan suatu rangkaian dari sejumlah kebutuhan naluri makhluk manusia yang berhubungan dengan seluruh kehidupannya. ${ }^{9}$ Kebutuhan manusia menciptakan rumah sebagai identitas budaya dalam bentuk seni arsitektur merupakan bagian dari kebudayaan dan manifestasi dari nilai-nilai budaya, baik nilai-nilai budaya perseorangan ataupun nilai-nilai budaya kelompok masyarakat. Oleh karena itu setiap pergeseran ataupun perubahan yang terjadi dalam kebudayaan akan mempengaruhi dinamika arsitektur (MADIASWORO, 2010). ${ }^{10}$

Rumah tradisional dengan konsep tata ruang yang berbeda beda merupakan manifestasi dari nilai-nilai budaya kelompok masyarakat. Tata Ruang Rumah Tradisional merupakan hal yang khas pada setiap kelompok masyarakat yang ditentukan oleh system nilai budaya dan merupakan simbolisasi dari kenyataan alam dan sosial budaya masyarakat, sehingga tata ruang menjadi sangat penting 
Maulana Kurniawan Putra, Junita Br Surbakti, Mailinar: Fungsi Arsitektur Rumah Tradisional Masyarakat Melayu Jambi di Seberang Kota Jambi

dalam pembangunan, terutama terkait dengan pembangunan permukiman dan perwilayahan. Konsep asitektur tata ruang dengan menggunakan pendekatan fungsionalisme menejalaskan bagaimana pandangan masyarakat Pelayangan Seberang Kota Jambi tentang tata ruang atau unsur unsur dari bagian rumah tradisional sebagai satu kesatuan yang mempunyai fungsinya dalam aktivitas masyarakat tersebut (Koentjaraningrat, 1987) ${ }^{11}$. Dengan mengerti dan memahami secara mendalam adat istiadat tentang arsitektur tata ruang suatu masyarakat, niscaya program pembangunan dengan permukiman dan perwilayahan juga tidak bertentangan dengan pandangan dan kebutuhan masyarakat bersangkutan(Cecep Eka Permana, 2006). ${ }^{12}$

Rumah dalam kebudayaan masyarakat Melayu Jambi, maupun masyarakat lain di Nusantara memang dianggap bagian penting, sama pentingnya dengan ikatan kekeluargaan yang dipertalikan dengan darah, atau dengan kata lain rumah adalah hiudp, pandangan hidup dan ekspresi dari kehidupan itu sendiri. Pandangan bahwa rumah sebagai bagian penting dalam konsep masyarakat Nusantara, Clifford Geertz (1996), menyebutnya sebagai 'stratigrafis', atau lapisan demi lapisan, antara hubungan yang satu dengan hubungan lain. Dalam konsep ini manusia adalah susunan 'taraf-taraf', dimana masing-masing mewakili lapisan dan pola-pola tertentu yang kemudian diekspresikan melalui symbol yang ditata sedemikian rupa dalam objek materialis, seperti misalnya rumah.

Dalam aktivitas sehari hari masyarakat Melayu seberang Kota Jambi menyebut rumah tradisional dengan istilah lokal yaitu umah bengen / Rumah Bengen (rumah lama), dimana Rumah Tradisional (Rumah Bengen) yang ada di Sebrang Kota Jambi Melayu bahan dasarnya terbuat dari kayu dan berusia 200 
sampai $400 \operatorname{tahun}^{13}$. Meskipun mengalami perubahan material dari bahan bakunya, namun tidak mengurangi keaslian bangunan rumah tradisional tesebut, istilah inipun semakin populer setelah pemerintah menetapkan Seberang Kota Jambi yang di kenal saat ini menjadi sebagai Kota Wisata Cagar Budaya ${ }^{14}$.

Dengan mengerti dan memahami secara mendalam adat istiadat tentang arsitektur tata ruang suatu masyarakat, niscaya program pembangunan dengan permukiman dan perwilayahan juga tidak bertentangan dengan pandangan dan kebutuhan masyarakat bersangkutan(Cecep Eka Permana, 2006). ${ }^{15}$

\section{Deskripsi Arsitektur Tata Ruang Rumah Tradisional dan Fungsinya Bagi Mayarakat Melayu Seberang Kota Jambi}

Rumah merupakan kebutuhan primer, sebagai tempat berlindung dari ancaman. Rumah merupakan bagian penting dan mempunyai makna tersendiri, artinya rumah bukan hanya sesuatu yang bersifat profan tetapi juga bersifat sakral. Bagi masyarakat melayu Jambi penerapan dan pembelajaran aturan tata sosial dimulai dari rumah, lalu ke lingkungan sekitarnya. Penjelasannya adalah sebagai berikut:

Umah deh umah pateli, umah belampit balembago, ka ateh batutup dengan bubung pirak, kabawah ba aleh badendi gading. Ka ateh batutup dengan bubung pirak itu yang dinamokan syarak, di bawah ba aleh basendi gading itu dinamaokan adat, syarak mengato adat memakai”. Seloko atau petuah dan nasihat adat melayu Jambi ini secara garis besar menjadikan struktur arsitektur rumah sebagai perumpamaan dalam berinteraksi sosial antara individu dengan

\footnotetext{
${ }^{13}$ Hasil wawancara dengan Bapak Ridwan (Wan). Rabu 4 Mei 2016, pukul 11.24 WIB s/d 12.30 WIB di tempat kediamannya.

${ }^{14}$ Hasil wawancara dengan Bapak Junaidi T. Noor. Senin 25 April 2016, pukul 10.00 WIB s/d 11.10 WIB di Kantor Lembaga Adat Melayu.
} 
idividu, individu dengan alam, dan individu dengan tuhan sang pencipta (Anra, Sadzali, Fakultas, Budaya, \& Jambi, 2018) ${ }^{16}$.

Seberang Kota Jambi merepresentasikan masyarakat asli melayu kota Jambi yang tinggal beserta adat istiadatnya. Masyarakat Seberang Kota Jambi masih mempertahankan adat istiadat dan tradisi lokal secara turun temurun. Menurut masyarakat, arsitektur rumah tradisional masyarakat Melayu seberang kota Jambi merupakan tradisi lokal turun temurun yang bangunan fisiknya sedikit banyak mendapatkan pengaruh dari wilayang sumatera seperti Palembang, Padang, dan Riau, sehingga arsitektur rumah tradisional mempunyai kemiripan, selain itu Jambi dan wilayah daerah bagian sumatera tersebut masuk dalam kategori ras yang sama yaitu ras Bangsa melayu ${ }^{17}$. Arsitektur rumah tradisional masyarakat Melayu seberang kota Jambi juga mendapatkan pengaruh dari perpaduan kebudayaan China, dan Arab, karena kehadiran kebudayaan sejak awal berkontribusi dalam membentuk kawasan Seberang Kota Jambi ${ }^{18}$. Berikut deskripsi arsitektur rumah tradisional masyarakat Melayu Sebarang Kota Jambi.

\section{Jenis Kayu}

Rumah tradisional di seberang kota Jambi umumnya masih memanfaatkan kayu sebagai bahan material utamanya. Masyarakat setempat biasanya menggunakan bebrapa jenis kayu sebagai alternatif dalam membuat rumah, antar lain beberapa jenis dan model kayu yang digunakan dalam pembuatan rumah tradisional masyarakat melayu seberang kota Jambi antar lain jenis kayu keras. Kayu keras biasanya digunakan sebagai tonggak utama dan bagian bagian

\footnotetext{
${ }^{17}$ Wawancara dengan Bapak Junaidi T. Noor dan Bapak Ridwan, Senin 25 April 2016, di Kantor Lembaga Adat Melayu.
}

\footnotetext{
${ }^{18}$ Wawancara dengan Bapak Amir, Sabtu 7 Mei 2016
} 
Maulana Kurniawan Putra, Junita Br Surbakti, Mailinar: Fungsi Arsitektur Rumah Tradisional Masyarakat Melayu Jambi di Seberang Kota Jambi

lainnya. Alasn masyarakat mengapa harus menggunakan kayu keras seperti Bulian, Tembesu, Kulim, dan Meranti karena bisa bertahan hingga ratusan tahun. Kayu jenis Bulian dan Tembesu, kayu Bulian biasanya digunakan untuk tonngakatau tiang rumah, sedangkan kayu tembesu digunakan sebagai rasukrasuk rumah hingga tiang rumah. Berikut gambar jenis kayu sebagi tiang utama rumah yang digunakan dalam pembuatan rumah tradisional masyarakt melayu seberang kota Jambi.
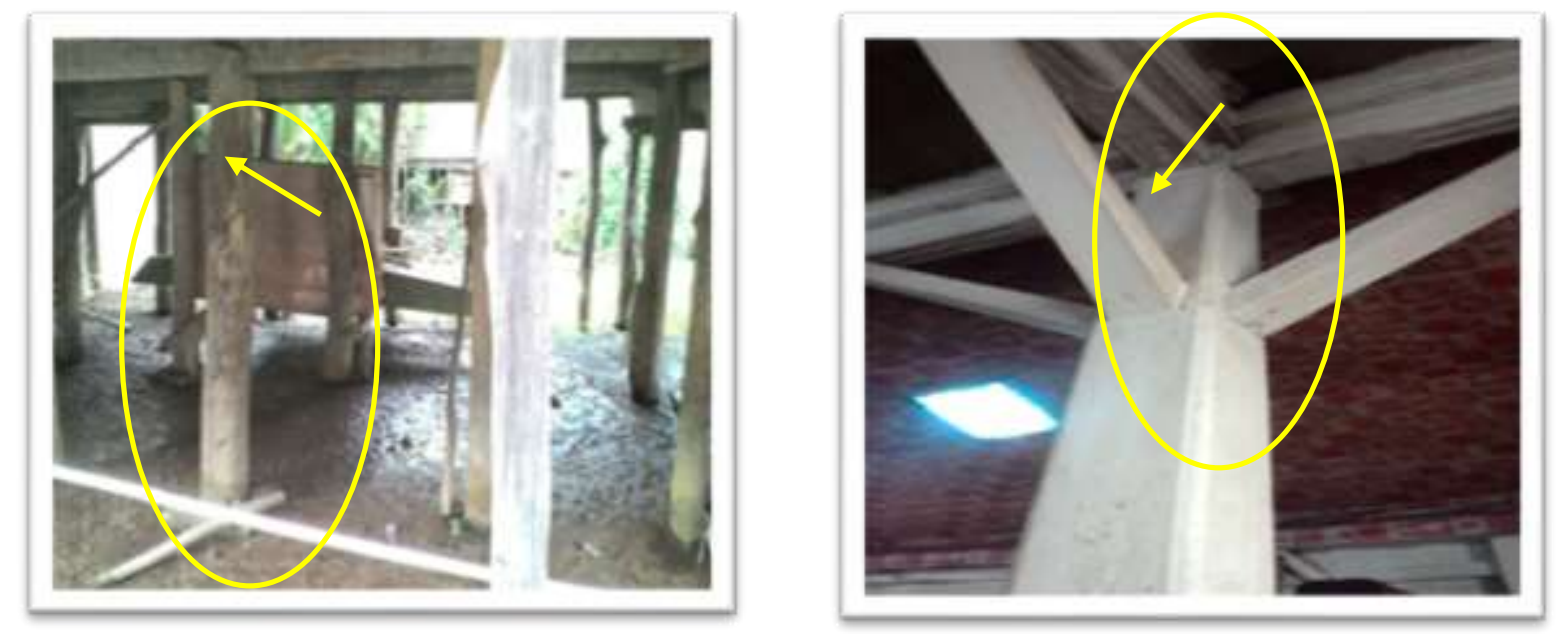

\section{Berpanggung}

Secara geografis wilayah seberang kota Jambi terletak di pinggir sungai, yaitu sungai Batanghari, sehingga desain Tata ruang rumah tradisional masyarakat Melayu seberang umumnya di desain dengan model berpanggung. Kebiasaan masyarakat dalam menetukan tinggi tiang rumah sangat berhubungan dengan konsep fungsional dari tata ruang tersebut. Fungsi panggung diantaranya untuk mencegah naiknya air sungai Batanghari yang bisa menyebabkan banjir. Tinggi tiang tidak ada ketentuan khusus, semua menyesuaikan dengan kebutuhan masyarakat setempat.

Rumah model panggung sebagai salah satu ruang bawah rumah oleh masyarakat digunakan untuk aktivitas seperti menumbuk padi, atau menumbuk beras, selain itu panggung merupakan salah satu usaha agar terhindar dari 
Maulana Kurniawan Putra, Junita Br Surbakti, Mailinar: Fungsi Arsitektur Rumah Tradisional Masyarakat Melayu Jambi di Seberang Kota Jambi

serangan binatang buas dan berfungsi sebagai tempat peralatan nelayan seperti perahu, dan ventilasi agar angin dengan leluasa masuk melalui dari bawah rumah 19. Rumah mode berpanggung menurut Goble (2007) dalam buku 'Traditional Building' merupakan arsitektur rumah tradisonal masyarakat Nusantara yang berpdoman pada konsep arsitketur austronesia; berbentuk persegi, memanjang kesamping atau kebelakang, berbentuk panggung, berbahan kayu dan bambu (Anra et al., 2018) ${ }^{20}$. Bentuk Panggung Pada Rumah tradisional Melayu Jambi seperti gambar dibawah ini.
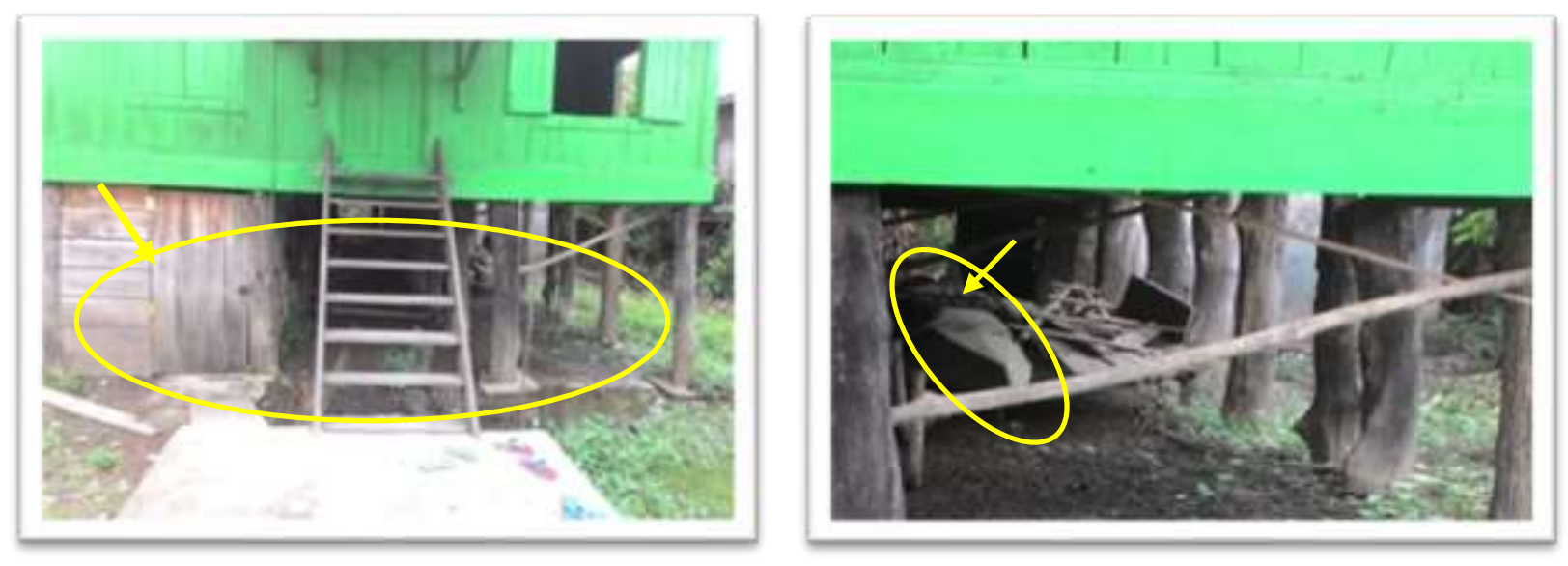

\section{Kolam Kecil Di Samping Tangga}

Rumah tradisional masyarakat Melayu Seberang Kota Jambi di lengkapi dengan kolam, kolam berukuran lebih kurang 1 meter x $1 \frac{1}{2} 2$ meter terbuat dari semen. Kolam yang dimaksud bukan untuk tempat memelihara ikan, tetapi kolam berfungsi sebagai salah satu tempat utnuk menampung air yang perkiraannya bisa menampung air lebih dari dua Qullah. Masyarakat menggunakan air tersebut untuk berwudhu dan untuk membersihkan atau mencuci kaki sebelum naik $\mathrm{k}$ atas rumah.

\footnotetext{
${ }^{19}$ Wawancara Bapak Ridwan, 25 April 2016
} 


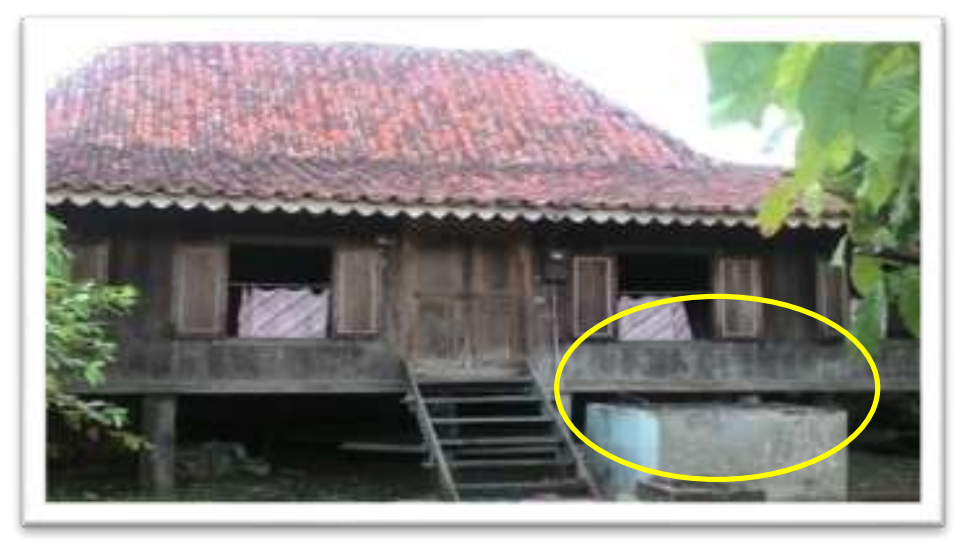

\section{Bertangga Depan dan Belakang}

Tangga merupakan sarana transportasi yang terdapat didalam gedung atau rumah. Jika tangga berada di luar gedung atau rumah maka ianya berfungsi sebagai sarana yang menghubungkan bagian luar rumah dengan bagain dalam rumah. Interaksi sosial antar tuan rumah dan tamu berawal ditangga depan. Tangga pada rumah tradisional masyarakat Melayu Seberang terdapat pada depan dan dibelakang rumah. Tangga depan dan belakang mempunyai fungsi yang berbeda. Anak Tangga Bagian depan berfungsi untuk naik kedalam rumah.

Terdapat istilah dalam seloko Jambi berkaitan dengan keberadaan anak tangga pada rumah tradisional melayu Jambi yaitu "melepas batuk di tanggo" seperti Ehmm, tamu memberikan simbol suara sebelum masuk rumah. Ini bermakna tamu ingin memastikan si empunya rumah berada dirumah. Istilah lain dalam seloko Jambi yang berkaitan dengan anak tangga yaitu "Bejenjang Naik, Betanggo Turun" artinya Desain tangga yang berada dibelakang berfungsi khusus untuk para kaum perempuan/keluarga yang mengurus keperluan dapur. Ketika ada tamu para perempuan melayu Jambi dilarang melewati tangga depan rumah $^{21}$.

\footnotetext{
${ }^{21}$ Hasil wawancara dengan Bapak Junaidi T. Noor. Senin 25 April 2016
} 
Maulana Kurniawan Putra, Junita Br Surbakti, Mailinar: Fungsi Arsitektur Rumah Tradisional Masyarakat Melayu Jambi di Seberang Kota Jambi

5.

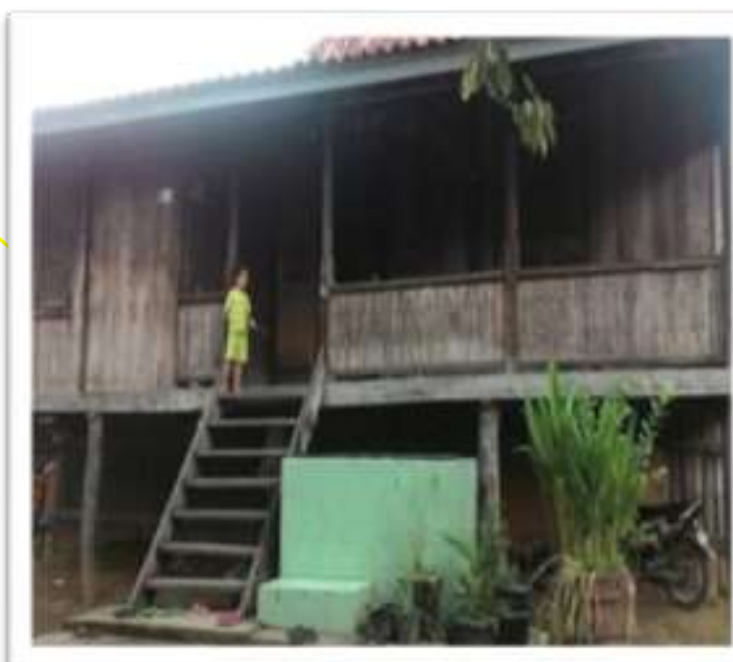

Rumah tradisional masyarakat melayu seberang kota Jambi mempunyai ciri

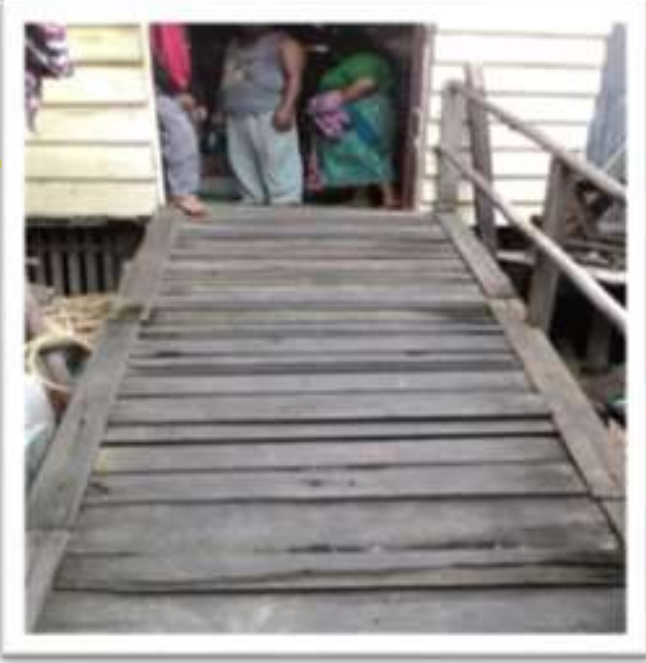

khas yaitu Ciri khas salah satunya ialah rumah tradisional masyarakat melayu seberang kota Jambi tidak menggunakan engsel sebagai penyatu antara daun pintu dan tiang pintu, dimana engsel yang digunakan terbuat dari daun pintu itu sendiri. Ciri berikutnya adalah adanya lawang (daun pintu), dimana pintu tersebut terutama pintu yang terdapat di depan rumah, tidak memiliki tinggi seperti rumah pada umumnya, pintu tersebut agak sedikit pendek, hal tersebut bertujuan agar tamu menghormati tuan rumah.
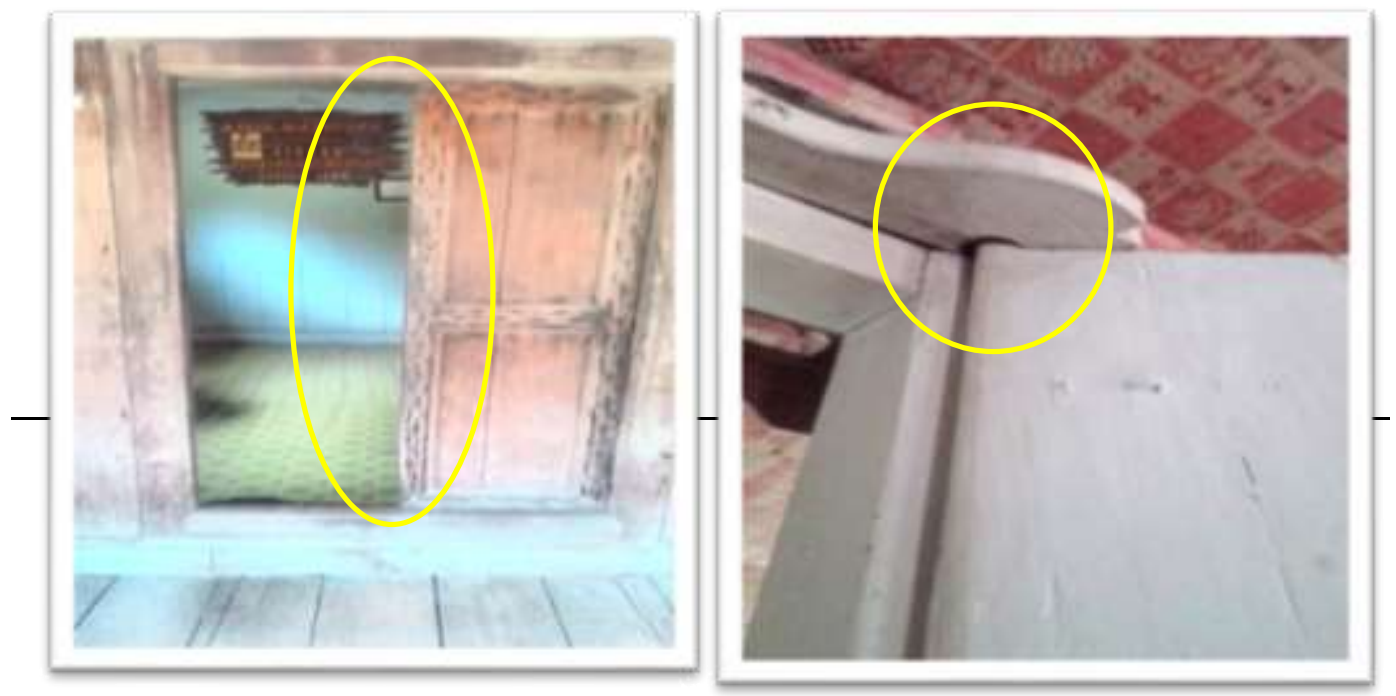
Maulana Kurniawan Putra, Junita Br Surbakti, Mailinar: Fungsi Arsitektur Rumah Tradisional Masyarakat Melayu Jambi di Seberang Kota Jambi

\section{Bendul}

Bendul yang dimaksud pada rumah tradisional masyarakat Melayu seberang kota Jambi adalah pembatas antara ruang satu dengan ruangan yang lainnya, dimana di setiap ruang di dalam rumah selalu terdapat bendul, dan ciri bendul tidak terlalu tinggi tapi menampakan batas antara ruang satu dengan lainnya. Bendul juga berfungsi sebagai pantang dan larang pemilik rumah, jadi tamu datang, tidak bisa sembarangan masuk ke ruang-ruang lainnya. Berikut gambar bendul pada rumah tradisional masyarakat Melayu seberang Kota Jambi
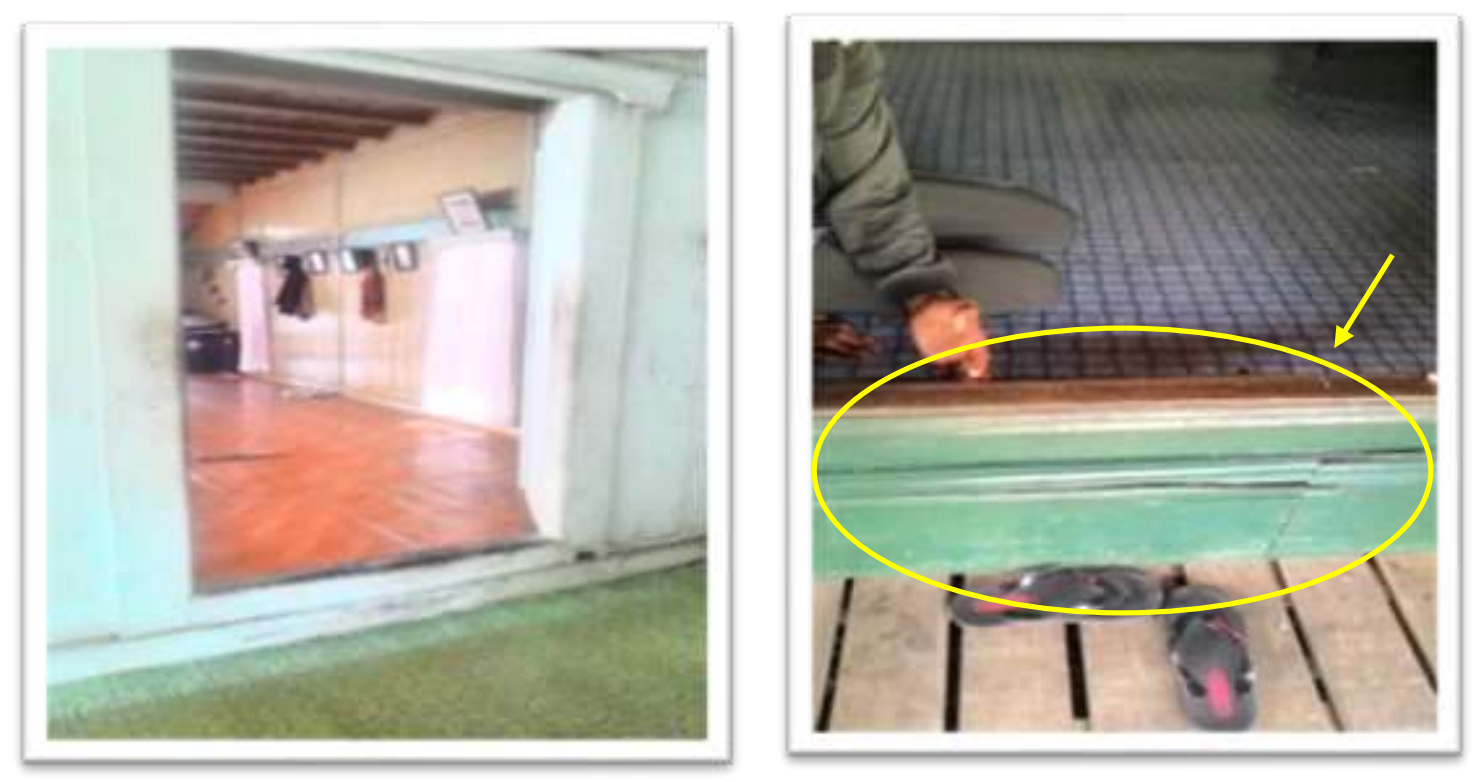

Pintu Kucing merupakan salah satu ciri yang merarik dalam arsitektur rumah tradisional pada masyarakat melayu seberang kota Jambi. Disebut pintu kucing, karena memang khusus dibuat untuk lalu kucing keluar masuk, agar bisa menangkap tikus dalam rumah. Pintu kucing berupa lobang kecil, yang seukuran dengan tubuh kucing, kemudian letak pintu kucing tersebut tepat di bawah pintu antara ruang tamu dan ruang makan. Pintu kucing dibuat sebagai rasa hormat terhadap binatang yang disayangi nabi. 
Maulana Kurniawan Putra, Junita Br Surbakti, Mailinar: Fungsi Arsitektur Rumah Tradisional Masyarakat Melayu Jambi di Seberang Kota Jambi

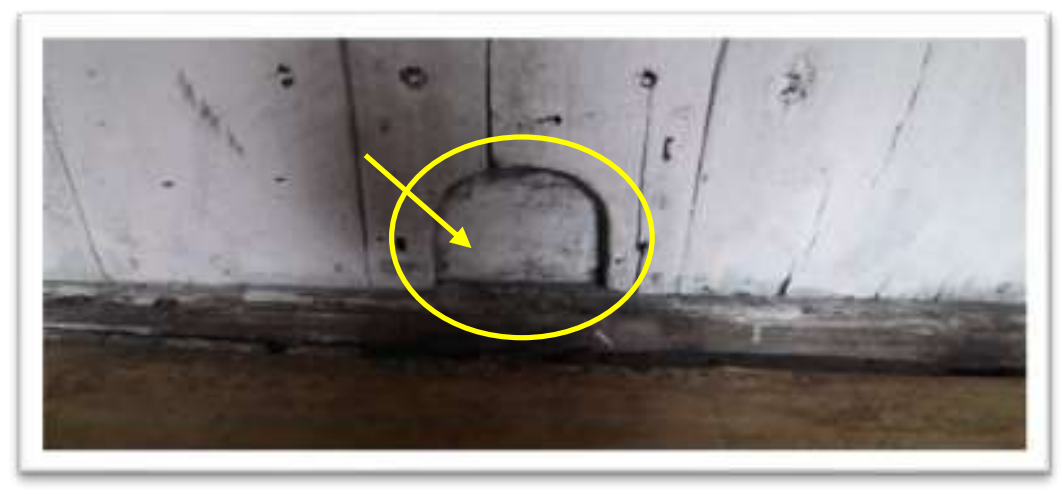

Pintu kucing dan berbagai arsitektur lainnya sebagai salah satu kekhasan yang dimiliki rumah tradisional melayu Jambi saat ini masih terjaga dengan baik. Di Seberang Kota Jambi tepatnya di Kecamatan Pelayangan, masih terdapat banyak rumah yang masih pelihara oleh masyarakat setempat bahkan jika ada yang rusak pemerintah akan melakukan pembugaran terhadap rumah tersebut, sebagai upaya pemerintah untuk mempertahankan cagar budaya yang di miliki oleh Jambi.

\section{Pengunci Rumah dan Engsel Jendela}

Bahkan terdapat masih di sebuah rumah adat melayu di seberang kota Jambi tepatnya di Kecamatan Pelayangan yang masih terjaga yakni kunci rumah serta engsel pintu yang sudah berumur ratusan tahun dan masih terlihat bagus. Dimana benda berikut terdapat di sebuah rumah masyarakat yang terletak di Kecamatan Pelayangan tepatnya di Kelurahan Tengah. Gambar pengunci rumah dan engsel jendela sebagai berikut:
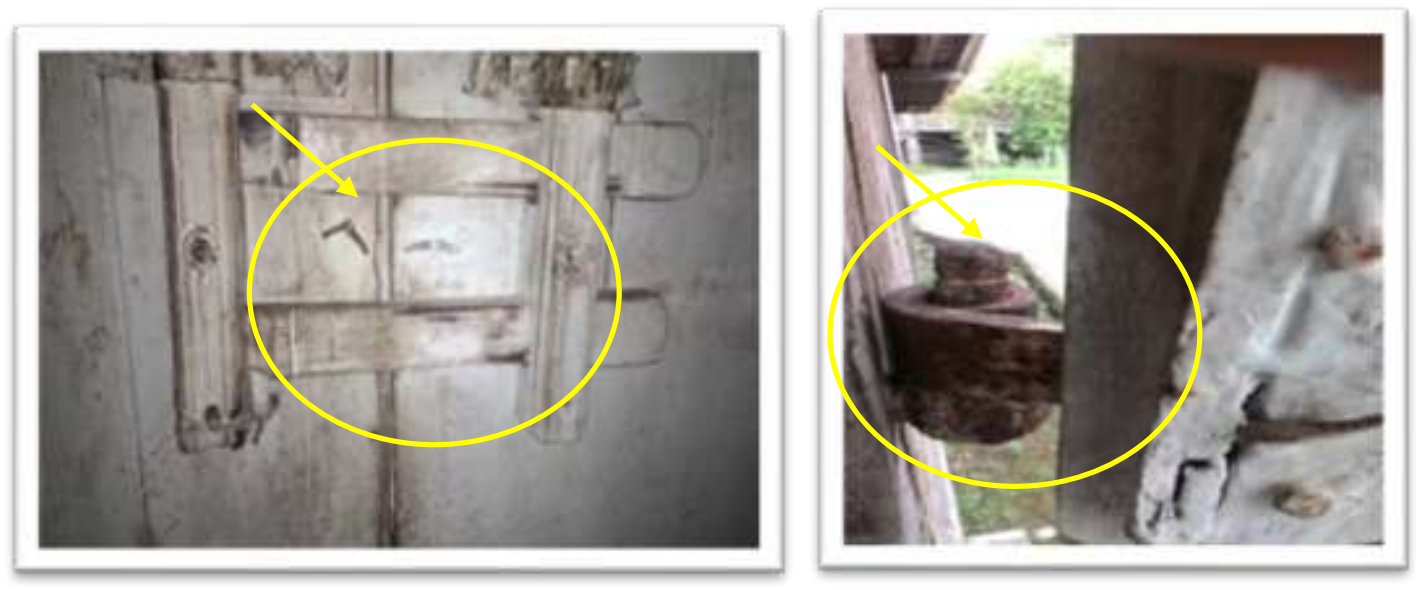

Nazharat, Vol. 26 No. 02, Desember 2020 
Maulana Kurniawan Putra, Junita Br Surbakti, Mailinar: Fungsi Arsitektur Rumah Tradisional Masyarakat Melayu Jambi di Seberang Kota Jambi

\section{Masyarakat Mempertahankan Rumah Adat Melayu Jambi}

\section{a. Unik}

Dengan semua keunikan khas yang dimiliki Rumah Adat Melayu Jambi, dan saat ini masih terjaga dengan baik. Di Seberang Kota Jambi tepatnya di Kecamatan Pelayangan, bahwa masih terdapat banyak rumah yang masih di jaga, baik dari pemerintah pusat yang melakukan pembugaran terhadap rumah tersebut, dimana hal tersebut juga sebagai upaya pemerintah untuk mempertahankan cagar budaya yang di miliki oleh Jambi. Karena keunikan dari rumah tersebutlah masyarakat Seberang masih mempertahankan rumah tersebut. seperti yang dikemukakan oleh salah seorang pemilik budaya, yaitu Bapak Yazid, selaku masyarakat seberang, sebagai berikut:

"ngapo orang masih mempertahankan rumah adat, rumah-rumah bengen yang di seberang ko, yang pertamo menurut sayo dari segi keunikannyo beda dari rumah-rumah zaman kini ko, tu yang pertamo.dak ado, apo, ee, tukang yang biso buat rumah bengen yang macam dulu, karno rumah dulu kebanyakan yo yang buat e tu, nyok ngupah orang dak, tapi orang rumah tu lah yang buat e, ha tu lah yang buat beda tu. keduo bahan e, mano bahan zaman dulu dengan zaman kini beda, tengok, sampe rumah yang tak betunggu be masih tegak kokoh, kini ko dak, tinggal setahun, dah rusak lah, kalo rumah bengen dak, boleh di tengok di sekitar seberang ko, rumah kosong tu yang rumah bengen, masih elok lagi, paling cuma di masuki rumput semak ko lah, tapi yang rumah tu masih tetap tegak kokoh, haa gitu.",22

\section{Transliterasi:}

"kenapa orang masih mempertahankan rumah adat, rumah-rumah lama yang di seberang ini, yang pertama menurut saya dari segi keunikannya yang berbeda dari rumah-rumah seperti saat ini, itu yang pertama. Tidak ada tukang yang bisa buat rumah lama yang seperti dulu, karena rumah dulu kebanyakan yang membuatnya itu tidak membayar orang, tapi orang rumah itu lah yang membuatnya, ha itu lah yang membuat berbeda. Kedua, bahannya, dimana bahan zaman

\footnotetext{
${ }^{22}$ Hasil wawancara dengan Bapak Yazid, Selasa 10 Mei 2016, pukul 12.30 s/d 13.30, di rumah kediamannya.
} 
Maulana Kurniawan Putra, Junita Br Surbakti, Mailinar: Fungsi Arsitektur Rumah Tradisional Masyarakat Melayu Jambi di Seberang Kota Jambi

dulu dengan zaman kini beda, lihat, sampai rumah yang tidak berpenghuni saja masih berdiri kokoh, kini ni tidak, tinggal setahun sudah rusak, kalau rumah dulu tidak, bisa di lihat di sekitar seberang ini, rumah yang lamo tu masih bagus, hanya Cuma di masuki rumput liar itu lah, tapi yang rumah itu masih berdiri tetap kokoh, haa gitu."

Disamping keunikan rumah tersebut yang membedakan, kemudian dari segi pembuatan, lalu bahan yang digunakan ataupun material rumah tersebut untuk saat ini sudah sangat sulit di temukan.

\section{b. Kearifan Lokal}

Adapun indikasi dari faktor masyarakat seberang mempertahankan rumah adat melayu Jambi tersebut ialah dimana rumah tersebut di pertahankan bukan hanya sekedar perintah dari orang tua akan tetapi rumah tersebut juga sebagai salah satu harta peninggalan ataupun harta warisan dari para orang tua terdahulu. Kemudian dari hasil wawancara tersebut dapat kita lihat, bahwa masyarakat mempertahankan rumah adat melayu tersebut bukan karena tidak ingin mengikuti perkembangan zaman modern saat ini, akan tetapi ada unsur lain yang membuat pemilik budaya tidak ingin merubah fisik rumah tersebut. Disamping hal tersebut juga dikarenakan mereka ingin berbakti kepada orang tua.

\section{c. Peninggalan Sejarah}

Masyarakat Seberang Kota Jambi yang selaku pemilik budaya tersebut, hingga saat ini masih mempertahankan Rumah Adat Melayu Jambi. meskipun mereka mengemukakan alasan yang variatif dalam mempertahankan rumah tersebut. Diantara alasan yang variatif tersebut salah satunya yaitu Dimana rumah tersebut mempunyai sejarah yang panjang, dan mereka tidak mau kehilangan sejarah tersebut. jika rumah tersebut harus di renofasi atau bahkan diganti dengan yang modern.

Dari hasil penjelasan wawancara dikarenakan rumah tersebut memiliki keunikan-keunikan yang berbeda dari rumah yang lainnya, 
Maulana Kurniawan Putra, Junita Br Surbakti, Mailinar: Fungsi Arsitektur Rumah Tradisional Masyarakat Melayu Jambi di Seberang Kota Jambi

meskipun rumah tersebut tersbuat dari bahan yang sama, serta bahannya yang langka dan memiliki ornament-ornamen arsitektur yang unik yang bahkan tidak terfikir oleh masyarakat saat ini. Disamping itu rumah adat melayu Jambi ternyata sebagai harta warisan dari orang tua mereka, hal ini lah salah satunya yang membuat pemilik budaya semakin mempertahankan rumah tersebut hingga saat ini.

Kemudian dari beberapa hasil penjelasan wawancara tersebut bahwa selaku pemilik budaya dari rumah adat melayu Jambi ialah betapa mereka sangat menghargai sebuah sejarah sehingga mereka tidak mau menghilangkan sejarah yang ada dan telah terjadi sekitar beberapa abad yang lalu.

\section{Fungsi Sosial dan Budaya Arsitektur Dari Model Rumah Adat Melayu Jambi}

Fungsi sosial ini di representasikan dari arsitektur ruang serambi luar dan dalam, ruang tengah, ruang laren, ruang garang, dan dapur. Dimana dari beberapa ruang tersebut ialah ruang yang terdapat di dalam rumah adat melayu Jambi. Rumah adat melayu Jambi memiliki ukuran yang besar, serta memanjang kebelakang, hal ini dikarenakan masyarakat Jambi memiliki keluarga yang banyak, disamping itu ketika salah satu anaknya ada yang menikah mereka akan menambah atau menyambung rumah kebelakang sehingga rumah tersebut bisa di tempati keluarga besar. ${ }^{23}$

Kemudian rumah tersebut tidak memiliki ukuran yang pasti untuk panjang dan lebarnya suatu rumah, hal tersebut dikarenakan pada zaman dulu kayu masih sangat mudah di temukan sehingga dalam pembuatan rumah terkadang mengikuti panjang kayu, jika panjang kayu 20 meter dan lebar 12 meter maka kayu

\footnotetext{
${ }^{23}$ Hasil wawancara dengan Bapak Syaid Abdullah, selasa 2 Mei 2016 pukul 13.00 WIB s/d 14.30 WIB di rumah kediamannya.
} 
Maulana Kurniawan Putra, Junita Br Surbakti, Mailinar: Fungsi Arsitektur Rumah Tradisional Masyarakat Melayu Jambi di Seberang Kota Jambi

tersebutlah yang akan menjadi titik ukurnya. Berawal dari hal tersebut lah sehingga rumah adat melayu Jambi memiliki ukuran yang tinggi-tinggi dan bahkan setiap ruang-ruang yang terdapat di dalam rumah adat melayu Jambi memiliki ukuran yang besar. Dimana dari ruang yang memiliki kapasitas lebih besar akan lebih mudah dan lebih banyak keluarga atau tamu yang bisa hadir ketika pemilik rumah mengadakan acara-acara seperti acara pernikahan, syukuran, ataupun acara-acara besar lainnya.

Kemudian dari rumah adat melayu Jambi terdapat beberapa ruang yang memiliki fungsi sosial serta kemudian di representasikan dari beberapa ruang tersebut seperti ruang serambi luar, serambi dalam, ruang tengah, ruang laren, ruang garang dan dapur. Dimana fungsi dari ruang tersebut ialah sebagai sarana tempat pertemuan dalam rangka menjaga silaturrahmi ataupun solidaritas sosial antar sesama, karena di ruang tersebut letaknya interaksi sosial ketika tamu ataupun keluarga yang datang bahkan ketika ada acara sekalipun ruang tersebut berfungsi untuk menampung keluarga yang besar.

Selanjutnya fungsi sosialnya adalah sebagai serambi luar. Serambi Luar yang lebih di kenal pada masyarakat umum saat ini ialah teras atau di sebut juga kaki lima. Serambi luar ialah salah satu bagian dari ruang yang terdapat pada rumah adat melayu Jambi, dimana serambi luar ini dulu berfungsi jika ada acara syukuran, kemudian kepala keluarga menunggu di serambi luar untuk menyambut para tamu. Akan tetapi saat ini serambi luar juga berfungsi sebagai tempat meletakan sandal atau sepatu dari pemilik rumah tersebut. Gambarnya adalah sebagai berikut:
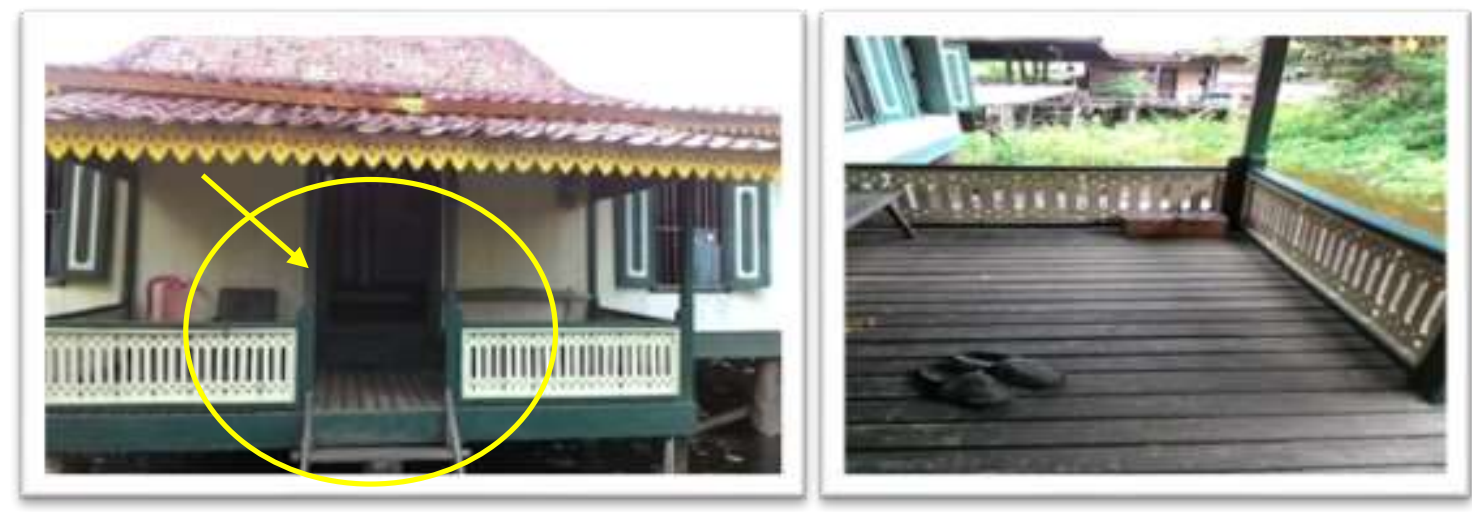

Nazharat, Vol. 26 No. 02, Desember 2020 
Maulana Kurniawan Putra, Junita Br Surbakti, Mailinar: Fungsi Arsitektur Rumah Tradisional Masyarakat Melayu Jambi di Seberang Kota Jambi

Kemudian setelah dari serambi luar masuk ke serambi dalam yang mana di antara ke dua ruang tersebut ada penanda yang mejadi pembatas antara ke dua ruang tersebut, yang biasa di sebut dengan Bendul. Serambi dalam yang dikenal masyarakat secara umum saat ini ialah Ruang Tamu, di ruang yang di sebut serambi dalam tersebut memiliki fungsi sosial sebagai tempat sarana pertemuan dalam rangka menjaga silaturrahmi ataupun solidaritas sosial antar sesama. Apabila tamu tersebut masih ada ikatan keluarga, tempatnya di ruang tengah, apabila tamu biasa cukup di ruang Serambi Dalam saja. Akan tetapi disetiap ruang tersebut tidak bisa sembarang orang ataupun tamu yang datang bisa masuk ke ruang-ruang lainnya karena terdapat bendul yang sebagai pembatasannya. ${ }^{24}$

Kemudian di dalam ruang Serambi Dalam terdapat kamar, dan biasanya terdapat 1 sampai 2 kamar di dalam setiap ruang serambi dalam, dimana kamar yang berada di dalam ruang serambi tersebut berfungsi sebagai kamar anak lakilaki dan berfungsi sebagai kamar tamu. Apabila keluarga datang dan ingin menginap maka di tempatkanlah di kamar yang terletak di ruang serambi dalam tersebut. Seperti yang di kemukakan oleh Bapak Syaid Abdullah bahwa fungsi kamar anak laik-laki di letakan di depan rumah memiliki peran penting, terutama untuk keamanan rumah, sebagai berikut:

"di dalam serambi tu ado duo kamar tu, sebelah kiri dengan kanan, salah satunyo kamar tamu, satunyo iolah kamar untuk anak bujang, anak bujang ko sebagai pengawal istilahnyo, kalo misalkan ado apo-apo di depan rumah, anak bujang ko lah siap nunggu, ha gitu.,"25

\section{Transliterasi:}

Di dalam serambi itu ada dua kamar tu, sebelah kiri dengan kanan, salah satunya kamar tamu, satunya ialah kamar untuk anak laki-laki, anak laki-laki

\footnotetext{
${ }^{24}$ Hasil wawancara dengan Bapak Syaid Abdullah, Selasa 2 Mei 2016 pukul 13.00 WIB s/d 14.30 WIB di rumah kediamannya.

${ }^{25}$ Hasil wawancara dengan Bapak Syaid Abdullah, Selasa 2 Mei 2016 pukul 13.00 WIB s/d 14.30 WIB di rumah kediamannya.
} 
Maulana Kurniawan Putra, Junita Br Surbakti, Mailinar: Fungsi Arsitektur Rumah Tradisional Masyarakat Melayu Jambi di Seberang Kota Jambi

itu sebagai pengawal istilahnya, kalau misalkan ada apa-apa di depan rumah, anak laki-laki itu sudah siap menunggu, ha gitu."
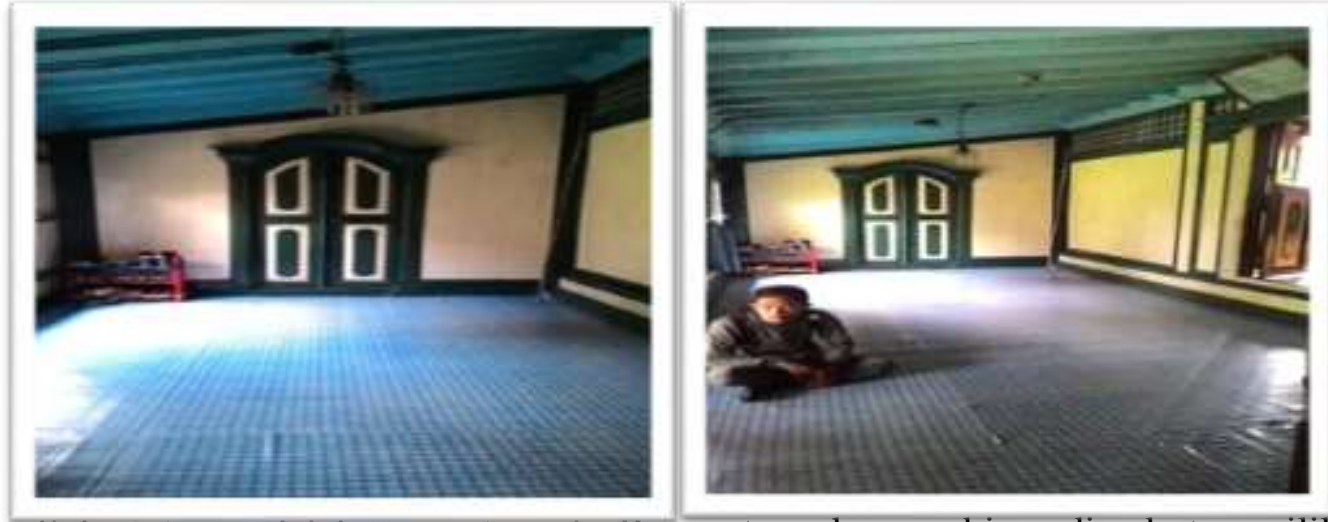

Selanjutnya adalah ruang tengah. Ruang tengah yang biasa di sebut pemilik

rumah ialah ruang dimana kegiatan aktifitas keluarga berkumpul bersama, ruang tengah menjadi salah satu ruang yang paling tinggi di banding dengan ruang yang lainnya, disamping itu ruang tengah terdapat kamar kepala keluarga yang menjadi pemimpin dalam rumah tersebut. ${ }^{26}$ Ruang tengah di fungsikan juga sebagai tempat berkumpul jika di dalam rumah tersebut sedang membuat acara. ${ }^{27}$ Kemudian di dalam ruang tengah tersebut terdapat dua buah kamar, dan terletak di sebelah kanan jika dari pintu masuk, dimana kamar tersebut ialah tempat seorang kepala keluarga, dan kamar yang sebelahnya ialah khusus kamar untuk seorang anak gadis.
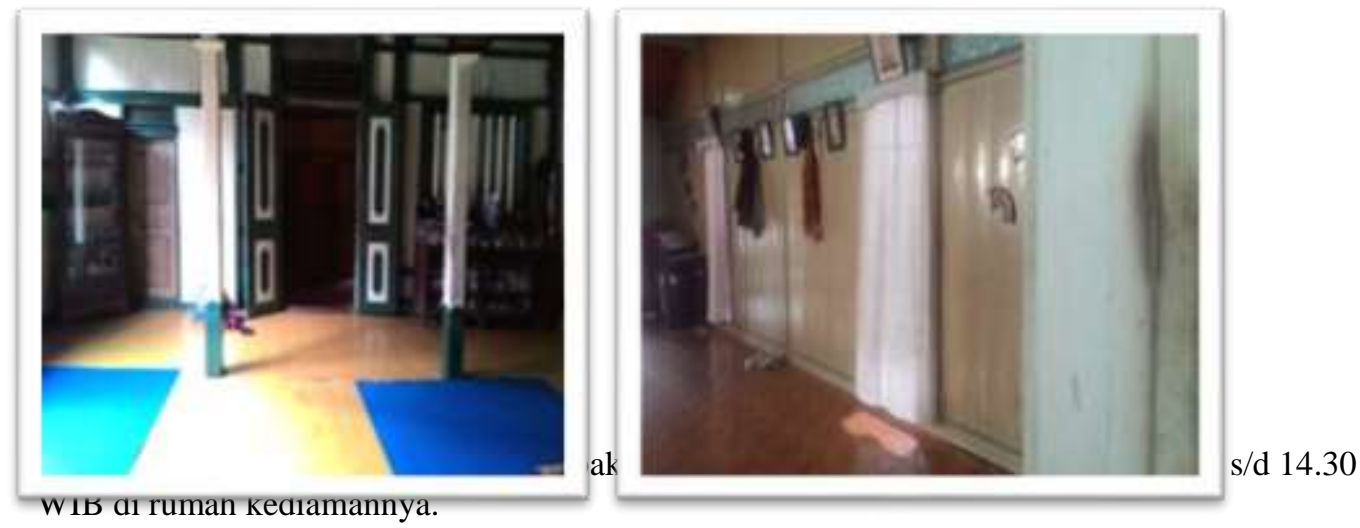

${ }^{27}$ Hasil wawancara dengan Bapak Syaid Abdullah, Selasa 2 Mei 2016 pukul 13.00 WIB s/d 14.30 WIB di rumah kediamannya. 
Maulana Kurniawan Putra, Junita Br Surbakti, Mailinar: Fungsi Arsitektur Rumah Tradisional Masyarakat Melayu Jambi di Seberang Kota Jambi

Laren ialah salah satu ruang yang berada di belakang setelah melewati ruang tengah, nama laren biasa di sebut dengan masyarakat dulu. Seperti yang di kemukakan oleh bapak Syaid Abdullah, sebagai berikut:

"bagi sayo cuman tau paling-paling namonyo, kareno orang tuo sayo dulu masih manggil namonyo tu, 'ambek itu di laren' katonyo tu kan, ha ambek tu dimano genah ee, ha tu, oh ini namonnyo laren." 28

Transliterasi:

"bagi saya hanya mengetahui namanya, karena orang tua saya dulu masih memanggil namanya seperti itu, 'ambil itu di laren' katanya kan, haa ambil itu dimana tempatnya, ha itu, ooh, ini namanya laren."

Dimana ruang laren tersebut memiliki fungsi sosial yaitu sebagai ruang makan keluarga, tempat ruang laren berada diantara ruang tengah dan ruang dapur.

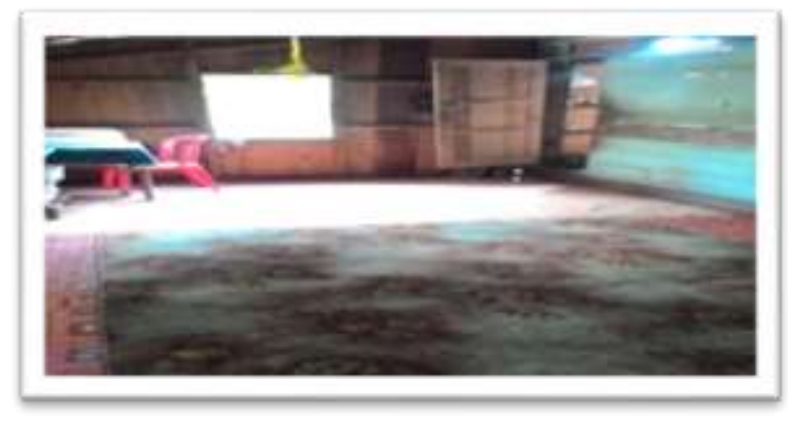

Bagian lainnya dari rumah adat Melayu Jambi adalah Garang. Garang adalah salah satu ruang yang berdekatan dengan dapur dan ruang makan, fungsi sosial dari ruang garang ialah sebagai tempat untuk mencuci baju, piring, menjemur pakaian dan keperluan keluarga yang lainnya. ${ }^{29}$ Model ruangan garang tidak memiliki atap pelindung, akan tetapi garang tersebut hanya di tutupi keliling

${ }^{28}$ Hasil wawancara dengan Bapak Syaid Abdullah, Selasa 2 Mei 2016 pukul 13.00 WIB s/d 14.30 WIB di rumah kediamannya.

${ }^{29}$ Hasil wawancara dengan Ibu Nurhayati, Selasa 2 Mei 2016 pukul 13.00 WIB s/d 14.30 WIB di rumah kediamannya. 
Maulana Kurniawan Putra, Junita Br Surbakti, Mailinar: Fungsi Arsitektur Rumah Tradisional Masyarakat Melayu Jambi di Seberang Kota Jambi

dengan seng, hal ini di karenakan supaya matahari bisa masuk keruang tersebut, agar pakaian yang di jemur agar cepat kering.

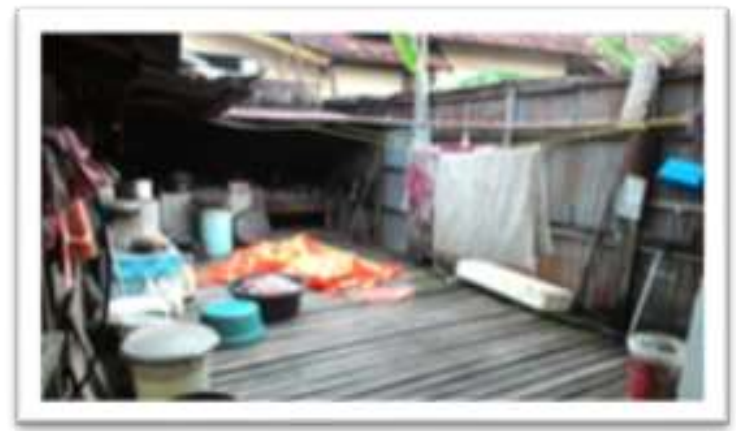

Letaknya yang berdekatan dengan ruang laren memudahkan kaum perempuan mengurus segalanya, sehingga ketika setelah selesai makan, barang atau piring kotor langsung di bersihkan di garang tersebut. Fungsi lainnya jika di dapur terjadi sesuatu yang tidak di inginkan seperti kebakaran, di ruang garang tersebut sudah tersedia air untuk memadamkan api kebakaran tersebut.

Dapur adalah ruang bagi para kaum perempuan, dapur berfungsi sebagai tempat masak-memasak bagi para kaum perempuan. Dari hasil observasi peneliti di rumah melayu sudah ada yang menggunakan dapur modern seperti kompor gas dan peralatan modern lainnya. Namun di rumah adat melayu yang lain masih menggunakan dapur yang lama yaitu masih menggunakan kayu bakar, seperti di rumah yang terletak di Kelurahan Tengah, masih menggunakan dapur yang lama, bahkan peralatan seperti batu giling, batu lesung, dan penggiling tepung masih ada terjaga dengan baik.

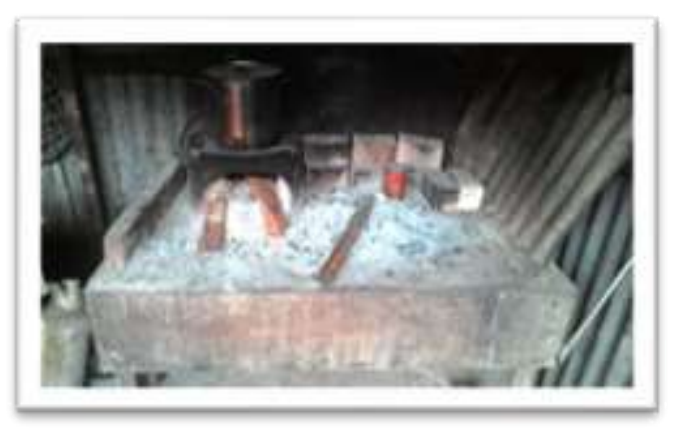

Rumah Adat Melayu yang terdapat di seberang kota Jambi tersebut memiliki keunikan yang khas, bahkan memiliki umur yang sangat tua, sehingga 
Maulana Kurniawan Putra, Junita Br Surbakti, Mailinar: Fungsi Arsitektur Rumah Tradisional Masyarakat Melayu Jambi di Seberang Kota Jambi

keberadaanya sangat di kenal sekali, bahkan karena umurnya yang sangat tua rumah adat melayu Jambi di tetapkan sebagai rumah cagar budaya oleh pemerintah daerah. Karena banyak dari rumah Adat Melayu di Seberang Kota Jambi tersebut mendapatkan bantuan berupa pembugaran, bahkan bedah rumah dari pemerintah. Karena untuk di jadikan sebagai rumah cagar budaya Jambi. Disamping itu bangunan-bangunan tersebut masih terjaga, meskipun terdapat renofasi yang di lakukan pemerintah, namun tidak mengubah dari bentuk fisiknya melainkan hanya mengganti bahan yang rusak ataupun tidak kuat untuk menopang bangunan tersebut.

\section{Simpulan}

Rumah tardisional masyarakat melayu seberang kota Jambi merupakan salah satu bentuk keraifan lokal yang mengusung konsep go green, hal ini bisa terlihat dari bahan baku yang terbuat dari kayu yang digunakan dan ramah lingkungan. Masyarakat melayu seberang kota Jambi memelihara keberadaannya dan berusaha untuk mempertahankan secara turun temurun sebagi rasa hormat terhadap keluarga terutama terhadap orng tua. Selian itu rumah tradisional merupakan proses panjang sejarah kehidupan ynag tidak boleh dilupakan karena rumah tradisional merupakan manifestasi nilai sosial dan budaya masyarakat melayu serang kota Jambi.

Alasan masyarakat mempertahankan rumah adat melayu secara umum masih terjaga dengan baik, hal tersebut dikarenakan rumah adat melayu tersebut memiliki keunikan yang khas dan masih terjaga hingga zaman yang sudah modern seperti saat ini. Kemudian alasan lain masyarakat mempertahankan rumah adat melayu di karenakan tidak ingin kehilangan nilai sejarah yang di miliki rumah tersebut, bahkan rumah tersebut ialah sebagai harta peninggalan dari orang tua mereka, kemudian di karenakan rumah tersebut memiliki ketahanan yang tidak dimiliki oleh rumah-rumah seperti saat ini.

Disamping hal tersebut secara tegas menyiratkan bahwa gencatnya modernisasi yang terjadi di Kota Jambi ternyata tidak sedikitpun mengubah 
Maulana Kurniawan Putra, Junita Br Surbakti, Mailinar: Fungsi Arsitektur Rumah Tradisional Masyarakat Melayu Jambi di Seberang Kota Jambi

persepsi masyarakat seberang kota Jambi terhadap Rumah Adat Melayu, hal tersebut di tunjukan dari masih banyaknya masyarakat yang menjaga keasrian rumah mereka masing-masing.

Fungsi sosial arsitektur dari model rumah adat melayu Jambi saat ini yang terdapat di kecamatan Pelayangan seberang kota Jambi juga masih terjaga dengan baik, bahkan dari segi fisik hingga ke fungsi sosialnya. Rumah tersebut memiliki beberapa ruangan yang kesemua ruangan tersebut memiliki fungsi sosialnya masing-masing, mulai dari serambi luar, serambi dalam, ruang tengah, ruang laren, ruang garang hingga kedapur. Dimana fungsi tersebut ialah sebagai sarana tempat pertemuan dalam rangka menjaga silaturrahmi ataupun solidaritas sosial antar sesama, kemudian ruang tengah ialah tempat berkumpulnya keluarga, atau juga sebagai tempat ketika mengadakan acara, lalu ruang laren ialah berfungsi sebagai tempat ruang makan keluarga, masuk ke ruang garang hingga ke dapur ialah berfungsi sebagai tempat para kaum perempuan menyelesaikan tugas-tugas dapur, seperti mencuci, menjemur, dll.

Persepsi masyarakat tentang keberadaan rumah tersebut dari hasil yang di dapat ialah rumah tersebut termasuk kedalam salah satu sebagai rumah cagar budaya Jambi, kemudian rumah tersebut ialah sebagai bangunan yang bersejarah. Disamping itu harus dilihat bahwa sebagai suatu nilai budaya wajib untuk melestarikan rumah tersebut untuk di jaga bahkan dilestarikan oleh pemerintah, karena rumah tersebut sudah sangat langka. Rumah tersebut juga termasuk sebuah peninggalan aset berharga bagi sejarah dan kebudayaan Jambi.

\section{DAFTAR PUSTAKA}

Anra, Y., Sadzali, A. M., Fakultas, A., Budaya, I., \& Jambi, U. (2018).

ARCHITECTURE VARIETIES OF JAMBI MALAY TRADITIONAL HOUSE:

A Study of Architectural Archeology in Conserving Cultural Heritage and Advancement of Jambi Malay Culture, 2(2).

Cecep Eka Permana. (2006). Tata Ruang Masyarakat Baduy.

Koentjaraningrat. (1987). Sejarah Teori Antropologi. Penerbit Universitas Indonesia.

MADIASWORO, T. (2010). PENGARUH KEBUDAYAAN BANJAR TERHADAP BENTUK RUMAH PANGGUNG MASYARAKAT BANJAR DI KAMPUNG MELAYU SEMARANG.

Meiske Widyarti, Budi Indra Setiawan, Hadi Susilo Arifin, dan A. S. Y. (2011). Konsep

Ecohouse pada Rumah Baduy Dalam. Jurnal Keteknikan Pertanian, 119-126. 
Maulana Kurniawan Putra, Junita Br Surbakti, Mailinar: Fungsi Arsitektur Rumah Tradisional

Masyarakat Melayu Jambi di Seberang Kota Jambi

Sudikno, Antariksa, P. S. (2016). MAKNA RUANG PUBLIK PADA RUMAH TRADISIONAL MASYARAKAT JAWA KASUS STUDI : DESA JAGALAN KOTAGEDE YOGYAKARTA, (March 2017).

https://doi.org/10.24853/nalars.15.1.1-12

Sulasman dkk. (n.d.). Teori-teori Kebudayaan Dari Teori Hingga Aplikasi.

Sumintardja, D. (1981). Kompendium Sejarah Arsitektur Jilid I. Bandung: Yayasan Lembaga Pendidikan dan Masalah Bangunan.

Tarigan, R. (2015). Tantangan pelestarian dan perubahan terhadap manfaat ruang tradisional akibat pengaruh kegiatan industri rumah tangga, 77-84.

Wiyana, B. (2016). Arti Tiang Rumah TRADISIONAL SUKU BATIN DI Kampung Baruh, JAMBI. 